\title{
Temesi István
}

\section{SZERV, SZERVEZET ÉS SZERVEZETRENDSZER A KÖZIGAZGATÁSBAN}

\section{Body, Organisation and System of Organisations in Public Administration}

Dr. Temesi István PhD, egyetemi docens, Nemzeti Közszolgálati Egyetem Államtudományi és Nemzetközi Tanulmányok Kar Lőrincz Lajos Közigazgatási Jogi Tanszék, temesi.istvan@uni-nke.hu

A közigazgatással foglalkozó tudományos munkák és a közigazgatásra vonatkozó joganyag magától értetődő természetességgel használja a szerv, szervezet, szervezetrendszer fogalmakat, pedig e fogalmak definiálása, valamint pontos és következetes használatuk több figyelmet érdemelne. A tanulmány a szerv és a szervezet fogalmakat és egymáshoz való viszonyát célozza vizsgálni többek között a jogi szabályozás segítségével. A vizsgált kifejezések használata mind a szakirodalomban, mind a jogi szabályozásban pontatlan és következetlen.

KulcssZavak:

hivatali szervezet, rendszer, szerv, szervezet, szervezeti egység, szervezetrendszer, szervrendszer

Scholars of public administration and related legal texts apply axiomatically the terms of body, organisation and system of organisations, however, their definition as well as their correct use should deserve more attention. This study aims at examining the notions of organ and organisation as well as their relatedness through an analysis of related legal texts. The use of these analysed expressions is inaccurate and inconsistent in both the literature and the legal texts.

KeYwORDS:

office arrangements, system, body, organisation, organisational unit, system of organisations, system of bodies 


\section{BEVEZETÉS}

A közigazgatás szervezetének számos sajátossága van. Talán a leginkább szembetűnő ezek közül a mérete. Néhány kivételtől eltekintve, egy adott államban a közigazgatás alkotja a legnagyobb szervezetet. Napjainkban e kivételek a globalizáció által életre hívtak olyan multinacionális vállalatokat, amelyek mérete adott esetben meghaladja egy nemzeti közigazgatás szervezetének méreteit. Egy olyan kiterjedt szervezet, mint a közigazgatás alkotóelemekből épül fel, amelyek meghatározható elvek szerint rendszert alkotnak. A közigazgatás szervezete tehát egy összetett rendszer, amelyet ezért szervezetrendszernek is szoktak nevezni, és amely alrendszerekből, illetve a rendszer legkisebb önálló alkotóelemeiből, közigazgatási szervekből áll. ${ }^{1}$ Jelen tanulmány megírásával célom, hogy megvizsgáljam a szerv, a szervezet és a szervezetrendszer fogalmak megjelenését és alkalmazását elsősorban a vonatkozó joganyagban, valamint ezek egymáshoz való viszonyát.

\section{SZERVEZET ÉS SZERV}

1. Jean Bodin az egyik legismertebb, Az államról címmel írt könyvében az embert a jól felépített állam hủ képének, ${ }^{2}$ illetve az emberi testet a jól szervezett állam mintapéldájának nevezte, amelyben „egyetlen tag sincs, mely ne kapna és adna valamilyen segítséget, s még a legtétlenebbnek látszó is megemészti a táplálékot a többieknek [...]". ${ }^{3}$ Thomas Hobbes az állami szervezeteket az állam olyan egyes részeinek tekintette, amelyek a természetes test megfelelő részeihez, vagyis az izmokhoz hasonlítanak. Szervezetnek pedig „bármilyen létszámú embercsoportnak közös érdek vagy ügy végetti társulását" nevezte. ${ }^{4}$ Látható, hogy az anatómiából átvett fogalmak használata egyáltalán nem ismeretlen az államtudományokban, így a jogtudományban és a közigazgatás-tudományban sem. A test, leginkább az emberi test, ha úgy tetszik az emberi szervezet és az állam mint szervezet összehasonlítása gondolatébresztő, aminek következtében érdemes megvizsgálni a szervezet fogalmának használatát és jelentését elsősorban a közigazgatás vonatkozásában, valamint a hatályos jogi szabályozásra támaszkodva.

2. Jogi értelemben szervezet az, amit a jog szervezetnek minősít. A jogi szabályozás ugyanakkor a szervezet fogalmát nem, csupán annak tartalmi elemeit határozza meg. A Polgári Törvénykönyvről szóló 2013. évi V. törvény (a továbbiakban: Ptk.) például úgy rendelkezik, hogy a jogi személynek az ügyvezetését és képviseletét ellátó szervezettel kell rendelkeznie, anélkül, hogy a szervezet fogalmát meghatározná. Ezzel szemben elöírja, hogy minden jogi személy szervezetének van döntéshozó szerve, ügyvezetése és képviselete (képviselője),

\footnotetext{
MADARÁsz 1992, 69.

BODIN 1987, 390.

BoDIN 1987, 346.

НоввеS 1999, 251.
} 
valamint lehetnek szervezeti egységei. ${ }^{5} \mathrm{Ez}$ a jogi szabályozás - tartalmát tekintve - részben megfelel a szervezet szociológiai fogalmának. Az egyik legismertebb szociológiai definíció szerint a szervezet olyan, kifelé szabályokkal korlátozott vagy zárt társadalmi kapcsolat, amelyben a kapcsolat rendjének betartását az erre specializálódó emberek - jellemzően egy vezető vagy az igazgatásban részt vevők csoportja - biztosítják. ${ }^{6}$

A polgári jogi szabályozásból következően a jogi személlyel szemben követelmény, hogy legyen szervezete, ugyanakkor ismert, hogy vannak jogi személyiséggel nem rendelkező szervezetek. A hatályos Ptk. nem ismeri a jogi személyiséggel nem rendelkező szervezet fogalmát, azonban arra az esetre elöír rendelkezést, ha „a közhatalmi jogkör gyakorlója nem jogi személy". Ebben az esetben azonban feltételezi a jogalkotó, hogy a közhatalmi jogkör gyakorlója - aki eljáró közigazgatási szervként minden esetben személy - a jogi személyiséggel rendelkező közigazgatási szerv keretében müködik.7 Jogi személyiséggel nem rendelkező szervezet a civil társaság, amelyet azonban nem a Ptk., hanem az egyesülési jogról, a közhasznú jogállásról, valamint a civil szervezetek müködéséről és támogatásáról szóló törvény intézményesít. ${ }^{8}$ A polgári perrendtartás a jogi személyiséggel nem rendelkező szervezet negatív definíciójával szolgál a nem természetes személy fogalmának meghatározása kapcsán. ${ }^{9}$

A szervezet kifejezés az Alaptörvényben változatos formákban jelenik meg anélkül, hogy a fogalom definiálva lenne, hiszen, eltekintve a „politikai szervezetekről és bünöző szervezetekről”, „a kommunista hatalmat birtokló szervezetekről”, továbbá ezzel kapcsolatban „társadalmi és ifjúsági szervezetekről” rendelkező U) cikkétől és a szervezetalakítás szabadságáról rendelkező VIII. cikktől, az Alaptörvény megnevezi a bírósági és az ügyészségi szervezetet. Előbbi a bíróságok szervezete, amely rendes bírósági szervezetből és közigazgatási bírósági szervezetből áll, ${ }^{10}$ és a szerkezeti egység címéből kiindulva, ami „A bíróság”, az a következtetés adódik, hogy a bíróság más szóval a bírósági szervezet, ${ }^{11}$ azonos a bíróságok szervezetével. ${ }^{12}$ Hasonló a helyzet az ügyészséggel, mert „Az ügyészség” cím alatt az Alaptörvény az ügyészi szervezetről ${ }^{13}$ és az ügyészség szervezetéről ${ }^{14}$ rendelkezik. Az Alaptörvény következetesen külön nevezi meg a Magyar Nemzeti Bankot, az Állami Számvevőszéket, a Magyar Honvédséget, továbbá a rendőrséget és a nemzetbiztonsági

Ptk. III. könyv, I. rész, III. cím, V. fejezet.

WEBER 1987, 72-73.

Ptk. 2:51. $₫(2)$ bek.

2011. évi CLXXV. törvény 5/A. \$(2) bek.

A polgári perrendtartásról szóló 2016. évi CXXX. törvény (a továbbiakban: Pp.) 7. \$ (1) bek. 15. pontja szerint nem természetes személy: a jogi személy, valamint a jogi személyiséggel nem rendelkező szervezet, amely jogszabályi rendelkezés alapján perbeli jogképességgel rendelkezik.

10 A kézirat lezárva 2019. november 11-én, amikor a közigazgatási bírósági reform annullálása még csak politikai nyilatkozat, nem jogszabály.

Alaptörvény 25. cikk (4) bek.

Alaptörvény 25. cikk (8) bek.

Alaptörvény 29. cikk (3) bek.

Alaptörvény 29. cikk (7) bek. 
szolgálatokat, valamint ezek szervezetét. ${ }^{15}$ Ezenkívül az Alaptörvényben megjelenik még a gazdálkodó szervezet és a nemzetközi szervezet kifejezés is.

3. Az Alaptörvény a szervezethez hasonlóan a szerv fogalmát sem definiálja. Az állami szervekre anélkül ró számos kötelezettséget, és biztosít azoknak jogosultságot, hogy az állami szerv fogalmát meghatározná. ${ }^{16}$ Ezenkívül az Alaptörvény megnevez, vagyis létrehoz szerveket: az Országgyűlés Magyarország legfőbb népképviseleti szerve; ${ }^{17}$ a Kormány a végrehajtó hatalom általános szerve és a közigazgatás legfőbb szerve, ${ }^{18}$ amely maga is jogosult államigazgatási szerveket létrehozni; a fővárosi és megyei kormányhivatal, amely a Kormány általános hatáskörü területi államigazgatási szerve; ${ }^{19}$ az önálló szabályozó szerv; ${ }^{20}$ az Alkotmánybíróság az Alaptörvény védelmének legfőbb szerve; ${ }^{21}$ a Kúria, amely a rendes bírósági szervezet legfőbb szerve; ${ }^{22}$ a Közigazgatási Felsőbíróság mint a közigazgatási bírósági szervezet legfőbb szerve; ${ }^{23}$ az Országos Bírói Tanács, illetve más bírói önkormányzati szervek; ${ }^{24}$ az Állami Számvevőszék, amely az Országgyűlés pénzügyi és gazdasági ellenőrző szerve ${ }^{25}$ valamint a Költségvetési Tanács, amely az Országgyűlés törvényhozó tevékenységét támogató szerv. ${ }^{26} \mathrm{Az}$ Alaptörvény ugyan expressis verbis ezt nem mondja ki, de a köztársasági elnök, a helyi önkormányzatok, az alapvető jogok biztosa és a Magyar Nemzeti Bank is a magyar állam szervei. Ezek közül a helyi önkormányzatnak és a Magyar Nemzeti Banknak maguknak is vannak szervei, amelyek jogszabályalkotásra jogosult szervek úgy, mint az önálló szabályozó szerv vezetője. Az Alaptörvény köztársasági elnökről rendelkező 9-14. cikkei az államföt nem nevezik meg szervként, ugyanakkor a T) cikk a jogalkotó szervek között nevesíti, következik ebből, hogy ez a minősége nem kérdőjelezhető meg. Azt, hogy a helyi önkormányzatok állami szervek, az N) cikk (3) bekezdése is megerősíti, amely szerint az Alkotmánybíróság, a bíróságok, a helyi önkormányzatok és más állami szervek feladatuk ellátása során az (1) bekezdés szerinti elvet kötelesek tiszteletben tartani.

Azon túl, hogy az Alaptörvény állami szerveket létesít, az alábbi, különböző típusú szervekről is rendelkezik:

- jogalkotó hatáskörrel rendelkező szervek,

- közfeladatot ellátó szervek,

\footnotetext{
Vö.: Alaptörvény 41. cikk (1) bek. és (6) bek., 43. cikk (1) bek. és (4) bek., 45. cikk (1) bek. és (5) bek., valamint 46. cikk (1) bek., (3) bek. és (6) bek.

Például Alaptörvény N) cikk (3) bek. és R) cikk (4) bek.

Alaptörvény 1. cikk (1) bek.

Alaptörvény 15. cikk (1) és (2) bek.

Alaptörvény 17. cikk (3) bek.

Alaptörvény 23. cikk.

Alaptörvény 24. cikk (1) bek.

Alaptörvény 25. cikk (2) bek.

Alaptörvény 25. cikk (3) bek.

Alaptörvény 25. cikk (5) bek.

Alaptörvény 43. cikk (1) bek.

Alaptörvény 44. cikk (1) bek.
} 
- a sajtótermékek és a hírközlési piac felügyeletét ellátó szerv,

- közhatalmat gyakorló szerv,

- államigazgatási szervek,

- közigazgatási szervek,

- alárendelt szervek,

- rendvédelmi szervek,

- különleges jogrend bevezetésére jogosult szerv.

\section{A KÖZIGAZGATÁSI SZERV ÉS A KÖZIGAZGATÁSI SZERVEZET VISZONYA}

1. Tekintettel arra, hogy a vizsgálódás célpontja elsősorban a közigazgatási szerv és a közigazgatási szervezet, ezek tágabb környezetének, vagyis az államszervezetnek az áttekintését követően szükséges megvizsgálni, hogy a közigazgatási jog logikája követi-e az Alaptörvényét. Kiindulva az eddigiekből, a szervezethez és a szervhez hasonlóan, közigazgatási szervnek is az minősül, amit a jogi szabályozás annak minősít. Ezt a jogi szabályozás vizsgálatával lehet igazolni. Ugyanakkor az eddig látottakhoz képest lényeges különbség, hogy a közigazgatási szerv fogalmát több jogszabály is definiálja. A kormányzati igazgatásról szóló 2018. évi CXXV. törvény (a továbbiakban: Kit.) Értelmező rendelkezésében, a 280. $\$$ (1) bekezdés 16. pontja a közigazgatási szerv fogalmát az alábbiak szerint határozza meg: a közszolgálati tisztviselőkről szóló törvény hatálya alá tartozó szerv és a kormányzati igazgatási szerv. Utóbbiakat, vagyis a kormányzati igazgatási szerveket a Kit. 2. \$-a sorolja fel. Előbbieket a közszolgálati tisztviselőkről szóló 2011. évi CXCIX. törvény (a továbbiakban: Kttv.) 6. $\$ 13$. pontja határozza meg. A Kttv. 6. $\$ 13$. pontja sem definíció, hanem csupán utaló szabály a Kttv. 1 . $\$$ és 2 . \$-ában felsorolt szervekre. Érdekesség, hogy ugyanennek a szakasznak a 17. pontja megismétli a közigazgatási szerv fogalmának meghatározását, azonban eltérő tartalommal, mint a 13. pont. A Kttv. 6. \$17. pontja a közigazgatási szerv fogalomkörébe a Kttv. 1. \$-ban és a 2. \$-ban meghatározott szerveken kívül bevonja a fövárosi és megyei kormányhivatalt is. Szokatlan megoldás, hogy ugyanazon jogszabály ugyanazon kifejezést két különböző tartalommal értelmezzen. A közigazgatási szerv Kttv.-ben meghatározott fogalmának alkalmazhatóságát szükíti az is, hogy azt kizárólag e törvény alkalmazásában rendeli el. Az imént ismertetett jogszabályi rendelkezésekből egy lényeges következtetés levonható: a Kit. a kormányzati igazgatási szerveket a közigazgatási szervek, illetve szervezetrendszer részének tekinti, és nem a közigazgatási szervek mellett, azokkal párhuzamosan müködő igazgatási szervezetet hozott létre.

2. Miután két törvényben is sikerült fellelni a közigazgatási szervek felsorolását, szükséges megvizsgálni, hogy a közigazgatási szervezet fogalma megjelenik-e, valamint definiálják-e. Ezt követheti a közigazgatási szerv és a szervezet viszonyának vizsgálata a jogi szabályozásban. 
A Magyarország helyi önkormányzatairól szóló 2011. évi CLXXXIX. törvényben (a továbbiakban: Mötv.) mind a szerv, mind a szervezet kifejezések számos alkalommal fordulnak elő. A teljesség igénye nélkül néhány példa, amely lehetővé teszi a jogszabályi szöveg további elemzését. A „közigazgatási szerv” kifejezéssel csupán egy esetben találkozunk: az Mötv. 16. $\$(1)$ bekezdésében jelzővel ellátva, mint „első fokon eljárt közigazgatási szerv”. Ezzel szemben a „szerv” kifejezés az alábbi kontextusban, illetve jelzőkkel jelenik meg az Mötv.-ben: az Alaptörvény 32. cikk (1) bekezdés j) pontja szerint megkeresett szerv; ${ }^{27}$ a hatáskörrel rendelkező szerv; ${ }^{28}$ más szerv (kizárólagos hatáskörébe); ${ }^{29}$ más állami szervek; ${ }^{30}$ az önkormányzat és a jogszabályban meghatározott állami szervek; ${ }^{31}$ költségvetési szerv; ${ }^{32}$ A helyi önkormányzatok, szerveik és müködésük; ${ }^{33}$ az Országgyülés, Kormány alárendeltségébe tartozó szerv; ${ }^{34}$ központi államigazgatási szerv; ${ }^{35}$ rendvédelmi szerv; ${ }^{36}$ gazdasági társaság legfőbb szerve; ${ }^{37}$ a képviselö-testület és szervei; ${ }^{38}$ az önkormányzat szervei; ${ }^{39}$ a társulás döntéshozó szerve; ${ }^{40}$ az illetékes szerv; ${ }^{41}$ más gazdálkodó szervek; ${ }^{42}$ a Kormány rendeletében kijelölt szerv; ${ }^{43}$ az Európai Számvevőszék és az Európai Bizottság illetékes szervezetei, kormányzati ellenőrzési szerv, a fejezetek ellenőrzési szervezetei, és a közreműködő szervezetek képviselői; ${ }^{44}$ a helyi önkormányzat és költségvetési szervei; ${ }^{45}$ az Országgyülés törvényben szabályozza a helyi önkormányzatok kötelező szervtípusait; ${ }^{46}$ felügyeleti szerv; ${ }^{47}$ az önkormányzati adattárházat müködtető szerv. ${ }^{48}$

3. A „szervezet” kifejezés előfordulása is gazdag és változatos az Mötv.-ben úgy, mint: nemzetközi szervezet; ${ }^{49}$ kényszerítő eszköz alkalmazására törvény alapján jogosult szervezet; ${ }^{50}$

\footnotetext{
Mötv. 7. $\$(1)$ bek.

Mötv. 7. $\$(2)$ bek.

Mötv. 10. $\$(1)$ bek.

Mötv. 12. $\$(2)$ bek.

Mötv. 16. $\$(6)$ bek.

Mötv. 16/A. $\$$ b) pontja.

Az Mötv. III. fejezet címe.

Mötv. 36. \$ (1) bek. a) pontja.

Mötv. 36. $\$(1)$ bek. b) pontja.

Mötv. 36. $\$(1)$ bek. d) pontja.

Mötv. 36. $\$(1)$ bek. h) pontja.

Mötv. 41. $\$(2)$ bek.

Mötv. 53. $\$$ (1) bek.

Mötv. 93. $\$ 5$. pontja.

Mötv. 109. \$ (5) bek.

Mötv. 112. $\$(1)$ bek.

Mötv. 114. \$ (4) bek.

Mötv. 119. \$ (1) bek.

Mötv. 119. $\$(6)$ bek.

Mötv. 125. $\$(1)$ bek.

Mötv. 142. $\$(2)$ bek.

Mötv. 143. $\$(1)$ bek. h) pontja.

Mötv. 16. $\$(1)$ bek.

Mötv. 17. $\$(1)$ bek.
} 
előadó-művészeti szervezet; ${ }^{51}$ érdekképviseleti szervezet; ${ }^{52}$ nemzetközi önkormányzati szervezet; ${ }^{53}$ a helyben érdekelt szervezetek; ${ }^{54}$ a társulás szervezete $;^{55}$ az Európai Számvevőszék és az Európai Bizottság illetékes szervezetei, kormányzati ellenőrzési szerv, a fejezetek ellenőrzési szervezetei, a kincstár, a közremüködő szervezetek; ${ }^{56}$ országos önkormányzati érdekképviseleti szervezetek; ${ }^{57}$ adatszolgáltatásra kötelezett szervezetek. ${ }^{58}$

Az Mötv. szabályozásának vizsgálata során arra a további következtetésre lehet jutni, hogy a közigazgatási szerv és a szervezet nem azonos tartalmú fogalmak, valamint, hogy egy közigazgatási szervnek lehet szervezete, ezzel szemben egy szervezetnek nem lehet szerve. ${ }^{59} \mathrm{Az}$ is kiolvasható a normaszövegből, hogy egy közigazgatási szervnek is lehet további szerve, illetve lehetnek szervei.

A fenti kijelentések igazolásához szükséges egyértelmüvé tenni, hogy a képviselö-testület szerv, jóllehet szervi minőségét sem az Mötv., sem az Alaptörvény expressis verbis nem mondja ki. Az Alaptörvényben elő sem fordul a képviselö-testület kifejezés. A képviselő-testület szervi minősége az Alaptörvény és az Mötv. szabályaiból közvetve vezethetö le. Az Alaptörvény a helyi önkormányzatot jogalkotó szervként nevesíti, amely önkormányzati rendelet néven jogosult jogszabályt alkotni. Az Mötv. ezt azzal egészíti ki, hogy a rendeletalkotás nem ruházható át a képviselö-testület hatásköréből. ${ }^{60} \mathrm{Az}$, hogy a képviselö-testület szerv és azon belül a helyi önkormányzat szerve, levezethető az Mötv. III. fejezetének címéből - A helyi önkormányzatok, szerveik és müködésük - is, de ez sem mondja ki expressis verbis, hogy maga a képviselő-testület az önkormányzat szerve.

A szerv és a szervezet különbözőségét illetően elegendő arra utalni, hogy jogszabály számos olyan szerv szervi minőségét állapítja meg, amely nem szervezet, illetve - a szervezet fogalmából kiindulva - nem lehet szervezet. Erre példa a jegyző vagy a polgármesteri hivatal ügyintézője. Ugyanez elmondható a Kormányról és a helyi önkormányzat képviselő-testületéről, amelyek közigazgatási szervek, de kérdéses, hogy maguk szervezetek-e, különös tekintettel arra, hogy jogosultak saját szervezetet létrehozni. ${ }^{61}$ Utóbbi paradox módon hangzik, hiszen logikai értelmezést kíván annak megértése, hogy egy szerv létrehozhat saját szervezetet, de önmaga nem szervezet. Furcsa eredményre vezet, ha analógiát vonunk az anatómiával, és azt mondanánk, hogy az embernek van saját szervezete,

\footnotetext{
Mötv. 13. $\$(1)$ bek. 7. pontja és 23. $\$(4)$ bek. 16. pontja.

Mötv. 42. \$5. pontja.

Mötv. 42. $\$ 6$. pontja.

Mötv. 54. $\$$.

Az Mötv. IV. fejezet egyik alcíme.

Mötv. 119. \$(1) bek.

Mötv. 131. $\$$ (1) és (2) bek.

Mötv. 143. $\$$ (1) bek. d) pontja.

59 Ez ellentmond az anatómia fogalomhasználatának, mert az emberi szervezetnek vannak szervei, és nem az emberi szerveknek van szervezete. Erről a kérdésről bővebben később.

$60 \quad$ Mötv. 42. \$1. pontja.

61 A Kormány - akkor még Minisztertanács - szervezeti minőségéről eltérő véleményt fogalmaz meg. MADARÁsz $1992,98$.
} 
de az ember maga nem egy szervezet. Ennél csak az lenne különösebb, ha azt mondanánk, hogy az ember a szerv, amelynek szervezete van - amellett, hogy további szervei vannak. Arra a kérdésre, hogy a Kormány szervezet-e, még később vissza fogok térni.

Azt a megállapítást, hogy egy szervnek lehet szervezete, alátámasztja például az Mötv. 42. \$2. pontjának rendelkezése, amely szerint a képviselö-testület hatásköréből nem ruházható át szervezetének kialakítása. Következésképpen a képviselö-testület, amely szervként funkcionál, rendelkezik szervezettel, amelyet maga alakít ki. A képviselö-testület saját szervezete kapcsán érdemes megemlíteni, hogy saját szervezetétől elkülönült, önálló szervezetet, tudniillik gazdálkodó szervezetet, nonprofit szervezetet és egyéb szervezetet alapíthat. ${ }^{62}$ Mindezek ellenére magát a képviselö-testületet mégsem nevezném szervezetnek.

A második megállapítást, miszerint a szervnek lehetnek szervei, a normaszöveg egyértelműen alátámasztja. A helyi önkormányzat, amelyet az Alaptörvény - jogalkotó - szervként nevez meg, az Mötv. III. fejezetének címe (A helyi önkormányzatok, szerveik és müködésük) szerint rendelkezik szervekkel. ${ }^{63}$ További példa az Mötv. 41. \$ (2) bekezdése, amely felsorolja a képviselö-testület szerveit, amihez kapcsolódóan meg kell említeni, hogy a képviselő-testület szervi minőségét nem vonjuk kétségbe. Az Mötv. 81. \$ (3) bekezdés e) pontja szerint a jegyző jelzi a képviselö-testületnek, a képviselö-testület szervének és a polgármesternek, ha a döntésük, müködésük jogszabálysértö. Kérdés, hogy a megállapítás érvényessége az Mötv.-n kívül kiterjeszthető-e más jogszabályokra is, és ezáltal általánosan a közigazgatási jogi szabályozásra. Ennek igazolására további példákat szükséges hivatkozni. A központi államigazgatási szervekről, valamint a Kormány tagjai és az államtitkárok jogállásáról szóló 2010. évi XLIII. törvény (a továbbiakban: Ksztv.) 2. \$ (1) bekezdés d) pontjának rendelkezéséből következik, miszerint a más szerv irányítása alatt álló központi államigazgatási szerveknek van szervezeti és működési szabályzata. Adódik tehát a következtetés, hogy a központi államigazgatási szerveknek, feltételezve azt, hogy más irányítása alatt állnak, van szervezeti és működési szabályzatuk, és ebből adódóan van szervezetük is.

A Kormány ügyrendjéről szóló 1144/2010. (VII. 7.) Korm. határozatban is találunk olyan rendelkezést, amely alátámasztja azt a megállapítást, miszerint egy szervnek lehetnek szervei. Az említett határozat 40. e) pontja szerint a Közigazgatási Államtitkári Értekezlet az általa tárgyalt előterjesztéssel (jelentéssel) kapcsolatban kikérheti a Kormány tanácsadó szervének a véleményét. Az 51. pont a Fejlesztéspolitikai Koordinációs Bizottságot a Kormány fejlesztéspolitikai javaslattevő, véleményező, döntés-előkészítő és koordináló szerveként nevezi meg. Következésképpen a Kormánynak, amely maga is szerv, vannak szervei. Ugyanezt mondhatjuk el a központi kormányzati igazgatási szervekről, amelyeknek a Kit. 2. \$-a szerint területi és helyi szervei vannak. További példa a Magyar Nemzeti Bank,

Mötv. 41. \$ (6) bek.

${ }^{63} \mathrm{Az}$, hogy a helyi önkormányzat szerv-e, aligha vonható kétségbe, miként a tudományos rendszertan alapján az sem, hogy közigazgatási szerv-e. Ennek ellenére az alapvető jogok biztosáról szóló 2011. évi CXI. törvény 18. \$ (1) bek. a) és b) pontja külön-külön nevesíti a közigazgatási szervet és a helyi önkormányzatot, mint amelyek tevékenysége vagy mulasztása esetén az alapvető jogok biztosához lehet fordulni. Ebből tévesen az következne, hogy a b) pontban nevesített helyi önkormányzat nem közigazgatási szerv, hiszen azt az a) pont nevezi meg. 
amelynek szerve annak elnöke ${ }^{64}$ vagy az önálló szabályozó szervek. Sem az MNB, sem az önálló szabályozó szervek szervi minősége kétségbe nem vonható, ugyanakkor az Alaptörvény az MNB elnökét, valamint az önálló szabályozó szerv elnökét nevesíti jogalkotó szervként. ${ }^{65}$

Az Mötv. arra is mutat példát, hogy egy szerv szervének is lehet szerve. Az Mötv. 41. $\$$ (2) bekezdése szerint a társulás a képviselö-testület szerve. Az Mötv. 94. \$ (1) bekezdése szerint az önkormányzati társulás döntéshozó szerve a társulási tanács. Következésképpen a képviselö-testület szervének - a társulásnak - a szerve a társulási tanács.

Miután számos példával igazolva kijelenthető, hogy egyes közigazgatási szerveknek lehetnek szervei, érdemes keresni néhány példát azon megállapítás alátámasztására is, miszerint egy közigazgatási szerv maga is hozhat létre közigazgatási szerveket. Ehhez jogszabályi felhatalmazás szükséges. Ennek megfelelően az Alaptörvény 15. cikk (2) bekezdése szerint a Kormány, amely a közigazgatás legfőbb szerve, törvényben meghatározottak szerint államigazgatási szerveket hozhat létre. Ez a megállapítás nem csak a közigazgatásra igaz, amit az államháztartásról szóló 2011. évi CXCV. törvény (a továbbiakban: Áht.) szabályainak hivatkozásával lehet igazolni. Az Áht. 8. \$ (1) bekezdése szerint költségvetési szerv alapítására jogosult központi költségvetési szerv esetén az Országgyűlés, a Kormány vagy a miniszter; helyi önkormányzati költségvetési szerv esetén a helyi önkormányzat - a közös önkormányzati hivatal esetén az Mötv.-ben foglaltak szerint az érintett helyi önkormányzatok -, a helyi önkormányzatok társulása, a térségi fejlesztési tanács, az átalakult nemzetiségi önkormányzat; nemzetiségi önkormányzati költségvetési szerv esetén a nemzetiségi önkormányzat vagy a nemzetiségi önkormányzatok társulása; köztestületi költségvetési szerv esetén a köztestület. Ugyanakkor nem minden közigazgatási szerv költségvetési szerv. A két fogalom nem azonos tartalmú. Példa erre a jegyző vagy a Kormány, amelyek közigazgatási szervek, de nem költségvetési szervek. A szerv és szervezet viszonyát tekintve, a költségvetési szerv fogalmának az egyik tartalmi eleme éppen annak a szervezete. Következésképpen a költségvetési szerveknek minden esetben van szervezete, a közigazgatási szerveknek nem feltétlenül. Előbbi kijelentést az Áht. II. fejezet 8. címe - A költségvetési szerv szervezete működése és képviselete - támasztja alá. A címből és a 10. \$ tartalmából az következik, hogy minden költségvetési szervnek rendelkeznie kell saját szervezettel, ami nem minden közigazgatási szervről mondható el.

Ez a megállapítás ugyanakkor nem csak a költségvetési szervekre igaz. A választási eljárásról szóló 2013. évi XXXVI. törvény (a továbbiakban: Ve.) 3. \$ (1) bekezdés 15. pontja szerint választási szerv a választási bizottság és a választási iroda. Következésképpen szervi minőségük nem kétséges. A Ve. a választási szervek közül egyet kiemel. Ez a Nemzeti Választási Iroda (NVI), amely autonóm államigazgatási szerv, egyben - fejezeti jogosítványokkal felruházott központi - költségvetési szerv, amely rendelkezik szervezeti és müködési szabályzattal. ${ }^{66}$ Következésképpen az NVI-n kívül egyetlen választási szerv sem

2013. évi CXXXIX. törvény 8. \$.

Alaptörvény T) cikk.

Ve. 53. $\$(1)$ bek., 54. $\$(1)$ bek. és 58. $\$(4)$ bek. 
rendelkezik saját szervezettel, és jogállásukat tekintve nem önálló költségvetési szervek, illetve szervezetnek sem nevezi öket a jogi szabályozás.

4. A szerv és a szervezet mellett jogi szabályozásunk további önálló kategóriaként ismeri - a szervezettől megkülönböztetve - a hivatali szervezet fogalmát, amely több jogszabályban is önálló megnevezés. A jogszabályi rendelkezések alapján az állapítható meg, hogy hivatali szervezete szervnek van, illetve lehet. A Kttv. vonatkozó rendelkezései alapján hivatali szervezete van az államigazgatási szervnek, ${ }^{67}$ valamint valamennyi törvényben meghatározott szervnek. ${ }^{68}$ Utóbbi rendelkezést a törvény szervi hatályát meghatározó rendelkezéssel együtt értelmezve, az a következtetésünk, hogy valamennyi olyan szervnek van hivatali szervezete, amelyre a Kttv.-t alkalmazni kell. Ha figyelembe vesszük, hogy a Kit. is számos alkalommal nevesíti a hivatali szervezetet ${ }^{69}$ akkor az a következtetés vonható le, hogy valamennyi közigazgatási szervnek lehet hivatali szervezete, ugyanakkor a saját szervezettel nem rendelkező szervek - mint például a miniszter vagy a jegyző - esetében a hivatali szervezet sem értelmezhető.

Érdekes kérdés, hogy a kormány szervezet-e, illetve van-e a kormánynak szervezete. Hivatali szervezete nincs, mert a jogi szabályozás a kormány munkáját segítő, a kormány saját szerveiről rendelkezik és nevesíti azokat, és nem találunk rendelkezést a kormány szervezetéről sem. Ezzel szemben Madarász Tibor - ugyan nem a kormány, hanem az annak megfeleltethető akkori - minisztertanács szervezetét, de nem a hivatali szervezetét, részletesen tárgyalja, és az azt alkotó tagokat tekinti szervezetnek. ${ }^{70}$ Annak ismeretében, hogy a szervezet fogalmát jogszabály nem definiálja, és kizárólag szociológiai fogalmakra hagyatkozhatunk, elfogadható, hogy a kormány maga is szervezet, és jóllehet ehhez egy logikai ugrás szükséges, de a kormánynak van (saját) szervezete is. Tény, hogy az eddig vizsgált jogszabályok nem tartalmaznak olyan rendelkezést, amelyek a kormányt szervezetnek neveznék. Ugyanakkor, álláspontom szerint a kormány megfelel Weber korábban idézett definíciójának. Ezzel szemben azt az álláspontot, hogy a kormány szervezet, nem erősíti, sőt, kifejezetten cáfolja, hogy a kormány müködését szervezeti és müködési szabályzat helyett ügyrend határozza meg, jóllehet a testületi szerveknek általában ügyrendje van, ezzel szemben a helyi önkormányzat képviselö-testületének szervezeti és müködési szabályzata. Ez a fogalomhasználat további kérdéseket nyit meg. Nevezetesen, a szintén testületi szervként müködő önkormányzati képviselö-testület müködését szabályozó dokumentumot miért nem ügyrendnek, és miért szervezeti és működési szabályzatnak nevezi a jogi szabályozás? ${ }^{71}$

\footnotetext{
Kttv. 75. $\$(5)$ bek.

Kttv. 125. $\$(1)$ bek.

Kit. 25. $\$(1)$ bek., 41. $\$(3)$ bek., 81. $\$(1)$ bek.

MADARÁsz 1992, 98.

További kérdés, hogy más testületi szervek esetében a plenáris ülés és a bizottság a szervezet alkotóelemei vagy a szerv müködési formái.
} 
A szerv és a szervezet fogalmak alkalmazása kapcsán a jogszabályokban alkalmazott fogalom a szervezeti egység. Korábban hivatkoztam a Ptk.-t, amelynek rendelkezéséből levezethető, hogy szervezeti egysége a jogi személy szervezetének lehet. A Ptk. tehát a szervezeti egységet a szervezet részének tekinti, amihez képest a közigazgatásban úgy tűnik, hogy szervezeti egysége a szerveknek lehet. Ezt támasztja alá a Ksztv. 3. \$ és a Kit. 4 . \$ rendelkezése. Előbbi szerint az államigazgatási szervnek, utóbbi szerint a kormányzati igazgatási szervnek lehet szervezeti egysége. A Kit. 28. \$-a fel is sorolja a minisztériumi szervezeti egységeket.

Az eddig vizsgált fogalmak legváltozatosabb formában és variációban talán a Kit.-ben lelhetők fel. A Kit. különböző rendelkezéseiből megállapítható például, hogy a minisztérium szerv, aminek van szervezete, és vannak szervezeti egységei, ezenkívül van hivatali szervezete is. ${ }^{72}$ A kormányzati föhivatal is szerv, amelynek van szervezete, vannak szervezeti egységei és lehetnek - területi - szervei. ${ }^{73}$ Ugyanez jellemzi a központi hivatalt, ${ }^{74}$ ami szintén szerv, amelynek van szervezete. A kormányhivatal az Alaptörvény 17. cikk (3) bekezdésének rendelkezése következtében szerv, amelynek van szervezete, szervezeti egységei, valamint hivatali szervezete. ${ }^{75}$

Érdekes kérdés, hogy a járási hivatal minek minősíthető. A Kit. 39. $\$$ (1) bekezdésének elemzése nem ad biztos támpontot. Kiindulva abból a rendelkezésből, hogy a kormányhivatal a kormánymegbízott által közvetlenül vezetett szervezeti egységekből és járási hivatalokból áll, juthatunk arra a következtetésre is, hogy szervezeti egység. A Kit. 39. \$ (1) bekezdése értelmezhető úgy, hogy a kormányhivatal kétféle szervezeti egységből áll: a kormánymegbízott által közvetlenül vezetett szervezeti egységekből és a járási hivatalokból mint szervezeti egységekből. Ugyanakkor az is egy lehetséges értelmezés, hogy a járási hivatal, jóllehet része a kormányhivatalnak, de nem szervezeti egysége. A fóvárosi és megyei kormányhivatalokról, valamint a járási (fóvárosi kerületi) hivatalokról szóló 86/2019. (IV. 23.) Korm. rendelet 2. \$ (6) bekezdése az utóbbi értelmezést erősíti, mert lehetővé teszi, hogy - a megyei kormányhivatal megyeszékhely szerinti - járási hivatalt feladatellátásért felelős szervnek jelöljön ki a Kormány. A kétségeket a hivatkozott rendelet 46. $\$$-a végképp eloszlatja, mert több feladat ellátására jogosult szervként jelöli meg a járási hivatalt. A 47. $\$$ pedig úgy rendelkezik, hogy a járási hivatalnak magának is van szerve, ez a kormányablak. Márpedig az eddigi fejtegetésekből nem következhet, hogy szervezeti egységnek saját szerve legyen, még akkor sem, ha hatásköre lehet.

5. Az eddig leírtakból következik, hogy a szerv, szervezet, hivatali szervezet fogalmak használata a jogi szabályozásban időnként ellentmondásosnak tűnik. Ezt néhány további példával érdemes alátámasztani. Az Mötv. 67. \$(1) bekezdése a képviselö-testülettel kapcsolatban úgy rendelkezik, hogy a polgármester a jegyző javaslatára előterjesztést nyújt be

\footnotetext{
Kit. 19. \$, 20. \$, 25. § és $28 . \$$.

Kit. 34. $\$$ és 35 . $\$$.

Kit. $36 \S$.

Kit. 39. § és 41. \$ (3) bek.
} 
a képviselö-testületnek a hivatal belső szervezeti tagozódásának, létszámának, munkarendjének, valamint ügyfélfogadási rendjének meghatározására. Az ebből adódó következtetés, hogy a polgármesteri hivatal szervezet, mert van belső szervezeti tagozódása, egyben van hivatali szervezete is, ugyanakkor szerv is, hiszen törvény mondja ki, hogy a képviselö-testület szerve. Kérdés még, hogy a polgármesteri hivatal kinek, illetve mely szervnek a szervezete: a képviselő testület szervezete vagy saját maga - belső - szervezete?

A Kit. is ad alkalmat arra, hogy gondolkodjunk. A Kit. 19. \$ (1) bekezdése a minisztériumot úgy definiálja, mint a miniszter munkaszerveként müködö, a Kormány irányítása alatt álló különös hatáskörü központi kormányzati igazgatási szerv. Ha ezt a rendelkezést összevetjük a Kit. 16. \$(1) bekezdésével, ami szerint a Miniszterelnöki Kormányiroda a miniszterelnök kormányzati igazgatási munkaszervezeteként működő különös hatáskörü központi kormányzati igazgatási szerv, akkor adódik a kérdés, hogy a minisztérium miért munkaszerv, miért nem munkaszervezet, vagy fordítva: a Miniszterelnöki Kormányiroda miért nem munkaszerv. Erre a kérdésre nehéz választ adni különösen akkor, ha tudjuk, hogy mind a minisztérium, mind a Miniszterelnöki Kormányiroda - kormányzati igazgatási - szervek.

A Kormány ügyrendje egyeztetési kötelezettséget meghatározó szabályai között találjuk azt a rendelkezést, amely szerint „tájékoztatást kell adni arról, hogy az elöterjesztö mely közigazgatási, társadalmi és egyéb szervezetekkel kivánja egyeztetni a tervezetet" ${ }^{76} \mathrm{Az}$ eddigiek ismeretében nem tünik következetesnek, hogy közigazgatási szervezetekkel kell egyeztetni, nem pedig közigazgatási szervekkel. Különös tekintettel arra, hogy az ügyrend ezt megelőző pontja azt írja elő, hogy a tervezetet véleménynyilvánításra a meghatározó országos önkormányzati érdekképviseleti szerveknek - tehát nem szervezeteknek - kell megküldeni. Ugyanakkor - szemben a tájékoztatási kötelezettség érintettjeivel, a közigazgatási szervezetekkel - előterjesztést szervek és személyek - tehát ebben az esetben nem szervezetek - nyújthatnak be a Kormányhoz. ${ }^{77} \mathrm{Az}$ ügyrend 52. m) pontja szerint a Fejlesztéspolitikai Koordinációs Bizottság a fejlesztések végrehajtásáért felelős szervezetektől beszámolót kérhet. A szerv és a szervezet fogalmak nem megfelelő - egyúttal nem következetes - használata azért szembetűnő, mert álláspontunk szerint a jogi szabályozásnak egy feladat ellátásának felelőseként feladat- és hatáskörrel rendelkező közigazgatási szerveket kellene, hogy megnevezzen, nem pedig közigazgatási szervezeteket. ${ }^{78}$ Ezt az álláspontot támasztja alá Madarász Tibor véleménye is, aki szerint „a(z államigazgatási) szervek tehát arra a feladatra jöttek létre, hogy a szervezetükön kívül elhelyezkedő személyeket és szervezeteket igazgassák" ${ }^{79}$ Erre - tehát a (közigazgatási) szerv és a szervezet közötti különbségre - mutat rá az Mötv. 90. $\$(1)$ bekezdése, amely szerint a társulás a feladatkörébe

1144/2010. (VII. 7.) Korm. határozat a Kormány ügyrendjéről 15. pont.

1144/2010. (VII. 7.) Korm. határozat a Kormány ügyrendjéről 26. (1) pont.

Ezt támasztja alá például a Ksztv. 2. \$(1) bek. f) pontja, amely szerint a szervnek van döntési joga és hatásköre. Ugyanígy az 5. \$ (2) bekezdése, amely szerint a szervnek lehet hatásköre és természetesen a szerv vezetőjének is lehet hatásköre.

79 MadARÁsz 1992, 70. 
tartozó közszolgáltatások ellátására - jogszabályban meghatározottak szerint - költségvetési szervet, gazdálkodó szervezetet, nonprofit szervezetet és egyéb szervezetet alapíthat. Ennek alátámasztására érdemes az általános közigazgatási rendtartásról szóló 2016. évi CL. törvény (a továbbiakban: Ákr.) 9. $\$$ rendelkezését hivatkozni, amely a hatóság fogalmát olyan szervként, szervezetként vagy személyként határozza meg, amelyet (akit) törvény, kormányrendelet vagy önkormányzati hatósági ügyben önkormányzati rendelet hatósági hatáskör gyakorlására jogosít fel vagy jogszabály hatósági hatáskör gyakorlására jelöl ki. Az Ákr. szóhasználata álláspontom szerint precíz, amennyiben azt úgy értelmezzük, hogy hatóságként eljárhat, illetve hatóság lehet közigazgatási szerv vagy nem közigazgatási szervezet. Ha utóbbi szervezet közigazgatási szervezet volna, akkor azt közigazgatási szervnek kell nevezni.

Ha azt állítjuk, hogy a szerv az, amelyik a hatáskört gyakorolja, és nem a - közigazgatási szervezet, akkor sajnos az Mötv. szabályozása sem következetes. Erre példa az Mötv. 119. \$ (1) bekezdése, ami szerint „[a] helyi önkormányzatnak nyújtott európai uniós és az ahhoz kapcsolódó költségvetési támogatások felhasználását az Európai Számvevőszék és az Európai Bizottság illetékes szervezetei, kormányzati ellenörzési szerv, a fejezetek ellenörzési szervezetei, a kincstár, az ellenőrzési hatóság, az európai uniós támogatások irányitó hatóságai és a közremüködö szervezetek képviselöi is ellenörizhetik”. Ebben a rendelkezésben a szerv és a szervezet kifejezések használata váltakozik. Kétséges az Mötv. 112. \$ (1) bekezdés következetessége is, amikor úgy rendelkezik, hogy „a helyi önkormányzat a feladatai ellátásának feltételeit saját bevételeibool, más gazdálkodó szervektöl” - és nem pedig, „más gazdálkodó szervektől” és gazdálkodó szervezetektől - „átvett bevételekből, valamint központi költségvetési támogatásból teremti meg".

A Kttv. 134. $\$(1)$ bekezdése az illetménykiegészítés mértékének megállapításával kapcsolatban sorol fel szerveket. Ebben a felsorolásban a 6. pont eleme a Nemzeti Földalapkezelő Szervezet. Ez ugyan tulajdonnév, amivel magyarázható lenne, hogyan került a különböző közigazgatási szervek közé, ugyanakkor a Nemzeti Földalapkezelő Szervezet elnevezés 2019. július 1-jétől annyiban változott, hogy a Nemzeti Földalapról szóló 2010. évi LXXXVII. törvény a Nemzeti Földalapkezelö Szervezetként a Nemzeti Földügyi Központot jelöli meg, egyben a Nemzeti Földalapkezelö Szervezetet az NFK a miniszter irányítása alatt álló központi költségvetési szervnek minősíti. ${ }^{80}$

Szintén a Kttv.-ben találjuk az alábbi, a „közigazgatási szervnél képviselettel rendelkező szakszervezet" fogalmát meghatározó rendelkezést: az a szakszervezet, amelyik alapszabálya szerint a közigazgatási szervnél képviseletére jogosult szervet müködtet, illetve tisztségviselővel rendelkezik. ${ }^{81}$ A szakszervezet fogalmát ugyanezen $\$ 30$. pontja úgy határozza meg, miszerint „munkavállalói érdek-képviseleti szerv. A közszolgálati tisztviselők minden olyan szervezete, amelynek elsődleges célja a közszolgálati tisztviselök kormányzati

80 Ezeknek az új rendelkezéseknek az ismeretében érdemes elgondolkodni azon, hogy a nemzeti földalapkezelő szervezet nem tulajdonnév, hanem köznév kellene-e, hogy legyen.

$81 \quad$ Kttv. 6. $\$ 18$. pont. 
szolgálati, illetve közszolgálati jogviszonyával kapcsolatos érdekeinek elömozdítása és megvédése. ${ }^{\$ 2} \mathrm{~A}$ 30. pont rendelkezéséből az következik, hogy a szakszervezet egyfelől - munkavállalói érdekképviseleti - szerv, másfelől - a közszolgálati tisztviselők - szervezete. Következésképpen szervezet és szerv is, valamint saját szerve is lehet, illetve azt müködtethet. Az érdekképviseletet ellátó szervek - vagy szervezetek - más jogszabályban is okoznak zavart. A bíróságok szervezetéről és igazgatásáról szóló 2011. évi CLXI. törvény (Bszi.) 76. \$ (3) bekezdés f) pontja érdekképviseleti szerveket nevesít, szemben a 106. $\$$ (1) bekezdésével, amely a „civil és egyéb érdek-képviseleti szervezet képviselöje” kifejezést használja.

A Ksztv.-ben is találunk ellentmondásosnak tünő rendelkezéseket. A Ksztv. 1. \$ (2) bekezdése szerint a rendvédelmi szerv központi államigazgatási szerv. Az 1. \$ (5) bekezdése a rendvédelmi szervek között nevezi meg a büntetés-végrehajtási szervezetet és a hivatásos katasztrófavédelmi szervet. Ebből azt a következtetés lehetne levonni, hogy szerv és szervezet között nincs különbség.

\section{A SZERVEZETRENDSZER}

A jogi szabályozás vizsgálata arra a következtetésre juttat, hogy a szerv és a szervezet fogalmát, ha nem is mindig következetesen, de gyakran használja a jogalkotó anélkül, hogy feladatának érezné azok definiálását, és ezt a feladatot meghagyja a tudomány számára. A szakirodalomban a közigazgatás szervezetével kapcsolatban gyakran használt kifejezés a szervezetrendszer. Ennek a fogalomnak is érdemes a jogszabályi megjelenését és az értelmezését analizálni.

Az eddig vizsgált jogforrások közül a szervezetrendszer elsősorban a törvények preambulumában jelenik meg, és csak kivételesen magában a normaszövegben. Az Mötv. preambuluma szerint „a helyi önkormányzatok az egységes állami szervezetrendszer részeként hozzájárulnak az Alaptörvényben foglalt államcélok megvalósitásához, elösegitik a jogszabályi kötelezettségek teljesitését". A Ksztv. preambuluma szerint a törvény megalkotásának célja a kormányzati szervezetrendszer működésének hatékonyabbá tétele. A Kit. preambuluma a törvény megalkotásának célját többek között a korszerű és hatékony kormányzati igazgatási szervezetrendszer kialakításában jelöli meg. A fővárosi és megyei kormányhivatalokról, valamint a fövárosi és megyei kormányhivatalok kialakításával és a területi integrációval összefüggő törvénymódosításokról szóló 2010. évi CXXVI. törvénynek szintén a preambuluma jelöli meg a törvény megalkotásának céljaként a területi államigazgatási szervezetrendszer működésének egységessé és hatékonyabbá tételét.

Természetesen minden közigazgatásra vonatkozó jogszabály teljes körü vizsgálatára nem volt lehetőség, azonban a fent említett jogszabályok elemzése azt mutatja, hogy a normaszövegben a szervezetrendszer kifejezés előfordulása ritka. Az Áht. az államháztartást nevezi rendszernek, amikor azt úgy definiálja, mint a közfeladatok ellátásának egységes

82 Kttv. 6. $\$ 30$. pont 
szervezeti, tervezési, gazdálkodási, ellenőrzési, finanszírozási, adatszolgáltatási és beszámolási szabályok szerint működő rendszere. ${ }^{83} \mathrm{Az}$ Áht. rendelkezik arról is, hogy az államháztartásnak mint rendszernek alrendszerei vannak. ${ }^{84}$ Kifejezetten a közigazgatásra vonatkozóan a szervezetrendszer kifejezés - a vizsgált jogszabályokban - két alkalommal lelhető fel. A 86/2019. (IV. 23.) Korm. rendelet 12. \$ (4) bekezdése a területi kormányzati igazgatási szerv által szervezett belső továbbképzések kapcsán közvetve nevezi a kormányzati igazgatási szerveket szervezetrendszernek. A Kormány tagjainak feladat- és hatásköréről szóló 94/2018. (V. 22.) Korm. rendelet pedig az ifjúsági szolgáltatások szervezetrendszerét nevesíti, amely működtetéséhez a miniszter igénybe veszi az Erzsébet Ifjúsági Alap Nonprofit Közhasznú Kft. és a Nemzeti Tehetség Központ Nonprofit Kft. szolgáltatásait. ${ }^{85}$

A szerv és a szervezet fogalmak alkalmazásához viszonyítva, a szervezetrendszer fogalom használatának mellőzése talányosnak nevezhető a közigazgatásra vonatkozó jogi szabályozásban. A talány megfejtéséhez a rendszer fogalmából kell kiindulni, amit a jogi szabályozás nem határoz meg. Ismét a szociológiához fordulva, a rendszer egymással funkcionálisan kapcsolatban álló, a környezettől e kapcsolatok és a kapcsolatrendszernek a környezet számára végzett funkciója által elhatárolható elemek összessége. ${ }^{86}$ A szervezet és a rendszer közötti összefüggésre tekintettel, a szervezet fogalmának egyik lehetséges értelmezése szerint a szervezet nem más, mint tudatosan létrehozott rendszer. ${ }^{87} \mathrm{~A}$ szervezet pedig, mint tudatosan létrehozott rendszer „egy vagy több cél elérésére egymással funkcionális kapcsolatban lévő" elemekből álló szerkezetet jelent, amelynek keletkezése általában a környezetből érkező döntés eredménye. ${ }^{88}$

A közigazgatás értelmezhető szervezetként, ${ }^{89}$ ugyanakkor egyben rendszerként is. ${ }^{90}$ Szervezetként és rendszerként is egy nagyobb rendszernek és így egy nagyobb szervezetnek, az államszervezetnek a része. Egyúttal a közigazgatás maga is viszonylag önállónak nevezhető rendszerekből áll. Ezek a közigazgatás alrendszerei, nevezetesen az államigazgatás vagy a helyi önkormányzati igazgatás, amelyek ugyanakkor rendszerek is, mert megfelelnek a rendszer kritériumainak, hiszen maguk is rendszerként müködnek. Az alrendszer elnevezés is helytálló, ez azonban viszonylagos, mert az alrendszer valamihez viszonyítva, nevezetesen egy rendszeren belül értelmezhető annak alrendszereként. Ugyanúgy, mintha a rész-egész viszonylatában jelentenénk ki a közigazgatásról, hogy része valaminek, ugyanakkor a részeire tekintettel maga is egy egészt - rendszert - alkot.

Az eddig leírtak ismeretében adódik a kérdés, hogy a közigazgatást mint szervezetet nem volna-e helyes szervrendszernek nevezni, szervezetrendszer helyett. A válasz felkutatása

\footnotetext{
Áht. 2. \$.

Áht. 3. \$ (1) bek.

94/2018. (V. 22.) Korm. rendelet 97. \$d) pont.

Tóth szerk. 1991, 59.; KulCsÁr 1988.

7 Ez az értelmezés társadalomtudományi. A természettudományi alkalmazása teológiai vita témája, amennyiben a kérdés az, hogy az élőlények szervezetének létrehozása tudatos tevékenység eredménye-e.

88 KuLCSÁr 1988, 61.

89 LŐRINCZ 2010, 19.

90 „Az államigazgatási szervezet az államigazgatási szervekből álló rendszer.” Lásd: MADARÁsz 1992, 69.
} 
elött - a bevezetőben hivatkozott fejtegetést követve - érdemes tájékozódni a természettudományokban. Az anatómia szerint szerv, ha a szöveteink egy meghatározott működés, feladat ellátása miatt tömörülnek. Szerv például a tüdő. A szervrendszer egy életműködés biztosítására együttműködő szervek összessége, például a légzés szervrendszere. A szervrendszerek összessége pedig a szervezet. ${ }^{91}$ „Az emberi testben szervek (organa) és szervrendszerek (systema organorum $=$ apparatus) találhatók. A szervrendszerek egy-egy élettani funkció ellátására szolgálnak, rendszerint közös fejlödéstani eredetüek, valamint anatómiailag is összeköttetésben vannak egymással, mint például az emésztörendszer (apparatus digestorius) vagy a légzörendszer (apparatus respiratorius). ${ }^{\text {'x2 }}$

Az állatélettan fogalmi rendszere hasonló. A szövetek szervekbe (organ) egyesülnek, az életfolyamatok pedig nemcsak egy-egy szervhez kapcsolódnak, hanem szervcsoportokhoz, amelyek egyes tagjai részfolyamatokat teljesítenek, és ezek integrálódnak egységes életjelenséggé. A szervek összessége az állati szervezet. A rendszer (systema) egyfelől jelent azonos szerkezetủ, működésủ, fejlődésủ szerveket, másfelől az eltérő szerkezetű, de közös funkciójú szervek rendszere a készülék (apparatus). ${ }^{93} \mathrm{Az}$ állati szervezetet pedig rendszerek és készülékek alkotják.

A nagyon korlátozottnak tekinthető természettudományi kitekintésből levonható következtetés, hogy az ember szervei szervrendszereket alkotnak, és a szervrendszerek alkotják az élő test szervezetét. Az a megállapítás sem téves, hogy a biológiai szervezetet szervek alkotják, különös tekintettel arra, miszerint a szervek összessége az állati szervezet, mint ahogyan az sem vonható kétségbe, hogy maga az élö szervezet is egy rendszer. Az ember szervezetét ugyanakkor mégsem szokták szervezetrendszernek nevezni, még akkor sem, ha tudjuk, hogy az emberi szervezet rendszerként funkcionál, és szervrendszerek - például a légzőszervek vagy az emésztőszervek, vagy a keringési rendszer - alkotják. Következésképpen az élő szervezetek esetében helytálló a szervrendszer kifejezés használata, de nem tűnik helyesnek a szervezetrendszer kifejezés használata. A közigazgatás esetében azonban más a helyzet, ami szintén egy olyan szervezet, amely rendszerként funkcionál, megfelel a rendszer fogalmi kritériumainak.

Abból kiindulva, hogy a szervek szervrendszert alkotnak, és a közigazgatás közigazgatási szervekből áll, arra a kérdésre, hogy a közigazgatás szervrendszer-e, igen a válasz. Ugyanakkor a közigazgatás önmaga is egy szervezet, mert egyfelől megfelel a szervezet fent hivatkozott definícióinak, másfelől a közigazgatás nem csupán szervekből áll, hanem szervezetekből is. Éppen a szerv és a szervezet megkülönböztetéséből következően értelmezhető a közigazgatás szervrendszerként és szervezetrendszerként is, vagyis e fogalmak nem szinonimák, és a szervezetrendszer mint fogalom nem felesleges. Bizonyos átfedés ugyanakkor van a két fogalom tartalmát tekintve. Amennyiben elfogadnánk azt, hogy a szervezetrendszer kifejezés használata felesleges, és helyette a szervrendszer kifejezés használata

Élettan I. é. n.

MiнÁLY 2006, 15.

www.agr.unideb.hu/ebook/allatelettan/az_llati_szervezetet_alkot_rendszerek_kszlkek.html (Letöltés dátuma: 2019. 10. 18.) 
helyesebb lenne, akkor ezzel azt ismernénk el, hogy a szervek és a szervezetek alkotta közigazgatásban a közigazgatási szerv és a közigazgatási szervezet között nincs különbség, következésképpen ezek azonosak. Lényeges szempont továbbá, hogy a közigazgatás fogalma szervi és funkcionális értelemben elválnak egymástól, amiből pedig az következik, hogy a közigazgatás szervezetrendszerében találunk olyan közigazgatási feladatokat ellátó szervezeteket is, amelyek maguk nem minősülnek közigazgatási szervnek. ${ }^{94}$

\section{5. ÖSSZEGZÉS}

Összegezve jelen tanulmány mondanivalóját, azt lehet megállapítani, hogy sem a jogi szabályozás, sem az ehhez gyakran kötődő szakirodalom nem következetes a közigazgatási szerv, szervezet, szervezetrendszer kifejezések használatában. A szakirodalom esetében természetesen nem mentség, de érdemes megemlíteni, hogy a szerv és a szervezet fogalmak alkalmazásakor a következetesség hiánya nem csupán a jelenkor sajátossága. Magyary Zoltán „a közigazgatás nagyszámú, részben törvényekkel szabályozott szerveit” a magyar állam fő szerveinek egyikeként említi. Magyary tehát a közigazgatást szervnek nevezi, amelynek magának is vannak szervei. Arra tekintettel, hogy mindezekről a Közigazgatás szervezete címü fejezetben ír, azt kell vélelmezni, hogy a közigazgatást egyben szervezetnek is tekintette. ${ }^{95} \mathrm{Ha}$ lenne is kétségünk, ez eloszlik, amikor Magyary azt írja, hogy „a közigazgatás hierarchikus szervezete az alacsonyabb és a magasabbfokú szervek különbözö fokozataiból áll". ${ }^{96}$ Érdemes arra is kitérni, hogy a szervezeti egység egészen eltérő jelentéstartalommal bírt, amit könnyű elfogadni, ha azt látjuk, hogy Magyary a magyar közigazgatás szervezeti egységeiként a közhatalmi egységeket (a közintézmények), a jóléti egységeket (a közintézetek és a köztestületek) és a gazdasági egységeket (közüzemek) nevezte meg. ${ }^{97}$ A szervezeti egység jelentéstartalmának gazdagságát mutatja, hogy Magyary a vármegyét is a közigazgatás egyik szervezeti egységeként aposztrofálta, ${ }^{98}$ amelynek szervezetéröl és szerveiről részletesen értekezett. ${ }^{99}$

A vizsgált kifejezések pontatlan és következetlen használata a jogi szabályozásban egyfelől minősíti jogalkotásunkat, másfelől beigazolódik, hogy a jog normatív szabályai nem feltétlenül tükrözik a valóságot, még akkor sem, ha van ilyen célú törekvés. Következésképpen, bizonyos esetekben erősen vitatható, hogy valóban szerv vagy szervezet az, amit a jogi szabályozás annak nevez.

\footnotetext{
94 A Magyar Kormánytisztviselői Kar a Kit. 76. \$-a szerint köztestület. Van szervezete és vannak ügyintézői, valamint van döntéshozó szerve. Erősen vitatható, hogy szerv lenne, de funkcionálisan - mivel ellát közigazgatási feladatot - a közigazgatás része.

95 Magyary 1942, 197.

96 Magyary 1942, 258.

97 Magyary 1942, 198.

98 Magyary 1942, 266

99 MAgYary 1942, 274-285.
} 


\section{FELHASZNÁLT IRODALOM}

1. Bodin, Jean (1987): Az államról. Válogatás. Budapest, Gondolat Kiadó.

2. Élettan I. (é. n.). Oktatási segédanyag. Elérhető: https:/ttf.hu/files/docs/egeszsegtudomanyi-es-sportorvosi-tanszek/lettan_I._oktat\%C3\%A1si_seg\%C3\%A9danyag.pdf (Letöltés dátuma: 2019. 10. 18.)

3. Новвеs, Thomas (1999): Leviatán I-II. vagy az egyházi és világi állam formája és hatalma. Budapest, Kossuth Kiadó.

4. KulCsár Kálmán (1988): Szociológia. Budapest, Kossuth Kiadó.

5. LöRINCZ Lajos (2010): A közigazgatás alapintézményei. Budapest, HVG-ORAC Kiadó.

6. Madarász Tibor (1992): A magyar államigazgatási jog alapjai. Budapest, Tankönyvkiadó.

7. Magyary Zoltán (1942): Magyar közigazgatás. Budapest, Királyi Magyar Egyetemi Nyomda.

8. MıнÁLy András (2006): Anatomia Essentialis. I. Kötet. Szeged, Szegedi Tudományegyetem Általános Orvostudományi Kar Anatómiai, Szövet- és Fejlődéstani Intézet.

9. Tóтн József János szerk.: (1991): Általános és politikai szociológia. Budapest, Államigazgatási Föiskola.

10. Weber, Max (1987): Gazdaság és társadalom. Budapest, KJK.

\section{Jogforrások}

1. Magyarország Alaptörvénye (2011. április 25.)

2. 2010. évi XLIII. törvény a központi államigazgatási szervekről, valamint a Kormány tagjai és az államtitkárok jogállásáról

3. 2010. évi LXXXVII. törvény a Nemzeti Földalapról

4. 2010. évi CXXVI. törvény a fövárosi és megyei kormányhivatalokról, valamint a fóvárosi és megyei kormányhivatalok kialakításával és a területi integrációval összefüggö törvénymódosításokról

5. 2011. évi CXI. törvény az alapvető jogok biztosáról

6. 2011. évi CLXI. törvény a bíróságok szervezetéről és igazgatásáról

7. 2011. évi CLXXV. törvény az egyesülési jogról, a közhasznú jogállásról, valamint a civil szervezetek müködéséről és támogatásáról

8. 2011. évi CLXXXIX. törvény Magyarország helyi önkormányzatairól

9. 2011. évi CXCV. törvény az államháztartásról

10. 2011. évi CXCIX. törvény a közszolgálati tisztviselőkről

11. 2013. évi V. törvény a Polgári Törvénykönyvről

12. 2013. évi XXXVI. törvény a választási eljárásról

13. 2013. évi CXXXIX. törvény a Magyar Nemzeti Bankról

14. 2016. évi CXXX. törvény a polgári perrendtartásról

15. 2016. évi CL. törvény az általános közigazgatási rendtartásról

16. 2018. évi CXXV. törvény a kormányzati igazgatásról

17. 1144/2010. (VII. 7.) Korm. határozat a Kormány ügyrendjéről 
- $\quad$ 18. 94/2018. (V. 22.) Korm. rendelet a Kormány tagjainak feladat- és hatásköréről

19. 86/2019. (IV. 23.) Korm. rendelet a fővárosi és megyei kormányhivatalokról, valamint a járási (fővárosi kerületi) hivatalokról

\section{Internetes forrás}

1. www.agr.unideb.hu/ebook/allatelettan/az_llati_szervezetet_alkot_rendszerek_ kszlkek.html (Letöltés dátuma: 2019. 10. 18.) 
Dr. Temesi István PhD, a Nemzeti Közszolgálati Egyetem Államtudományi és Nemzetközi Tanulmányok Kar Lőrincz Lajos Közigazgatási Jogi Tanszékének egyetemi docense. Főbb érdeklődési és kutatási területei: közigazgatás-tudomány, közigazgatási jog. Több mint 90 publikációt jegyez. 2006 óta a Fővárosi Választási Bizottság tagja, 2010-től elnöke. 2003 óta gyakorló ügyvéd. 